\title{
Why demonetize the Indian economy?
}

\author{
Augendra Bhukuth \\ ITSMI School of Management, \\ Paris, France \\ angendra@gmail.com \\ Bernard Terrany \\ Ipag Business School, Paris France \\ b.terrany@ipag.fr
}

Abstract. This paper is a conceptual analysis of demonetization. The main aim of this paper is to analyze the reason why a government would like to demonetize its economy. The main reasons for demonetizing an economy are to modernize the banking sector, to provide banks with liquidity, to reduce the importance of the informal financial sector, to give people the opportunity to hold bank accounts, which in turn gives people access to the credit market. This is part of the digitalization of the economy which is a part of the demonetization policy. The other aim of this policy is to fight against inflation and attract foreign direct investment. The make-in policy and demonetization policy are interrelated.

Received:

March, 2019

1st Revision:

July, 2019

Accepted:

November, 2019

DOI:

$10.14254 / 2071$ $8330.2019 / 12-4 / 1$

Keywords: demonetization, inflation, FDI, make in policy, banking sector, India.

JEL Classification: E42, E52, E63, F33

\section{INTRODUCTION}

The government of India has implemented some policies which are sharply criticized by the opposition parties about their effectiveness. The efficiency of these policies is in question. Several studies have tried to explain the impact of these policies on the economy (Choudhary et al., 2017; Guérin et al. 2017; RBI, 2017; Uke, 2017). It has been stated that this policy is implemented to fight against black money and corruption (Singhal et al., 2017; Mali, 2017). The argument of black money was used on purpose by the government to make it acceptable by all the Indians. Fighting against corruption and black money is one of the main concerns of the people as it is considered as the main disease of the economy. It is a great argument to value besides the people of India.

The objective of the paper is not to analyze the efficiency of this policy whether it effectively fights against black money but it aims to give a conceptual explanation to these policies, to understand the overhaul concept of the policies implemented by the government of India. Why has the government of 
India implemented the demonetization policy? This question is essential in understanding the objective of the government. The government has implemented several policies to boost the economic growth. These policies are make-in India policy (policy to attract FDI in the country), demonetization policy; which consists of replacing old currencies with new currencies consisting of 500 and 1000 notes and the GST policy (taxes on goods and services). Considering separately these policies and analyzing them without any connection does not help understanding the macroeconomic objective of the government. This paper is not focusing on GST policy, it is about the understanding of what the government of India is trying to do

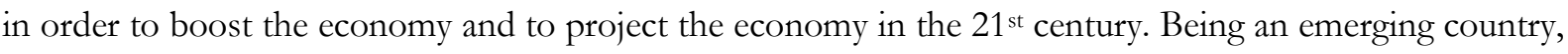
India wants to compete with its primary rival, China.

In order to analyze the policies implemented by the government of India we will consider a hypothetical case. This conceptual analysis gives a simple framework of the Indian government policies. It shows the coherences of the policies implemented and it seems that the policies are well planned to increase the economic growth and to provide the Indian economy with modern institutions capable to face international competition and to become a leading country.

In the first section the hypothetical model is presented, showing a suboptimal equilibrium in the market for goods and services because it assumes that the demand for goods and services is higher than the supply. The supply is lower than the demand because the capital is fixed and there is underemployment of labor. In the second section, it is argued that there is mismatch in the credit market mainly because banks do not have enough liquidity to satisfy the demand for credit. Firms would like to invest in the economy in order to satisfy the demand and reduce unemployment in the economy. In the third section, the reason why the state intervenes in the economy is presented. The credit practices are presented. It shows that the state has several objectives to fulfill by intervening in the economy. In section four, we show that the state implements the demonetization policy to fight against inflation but also to provide the banks with liquidity in order to facilitate lending to firms. In the fifth section it shows that the state intervenes in the banking sector in order to reinforce its make-in policy. The make-in policy is implemented to attract FDI (Foreign Direct Investment) in the economy. There is lack of capital in the economy and mainly high technology. The economy needs this kind of investment to boost its economic growth. In the sixth section, the main conclusions are presented.

\section{THE HYPOTHETICAL MODEL}

Let's consider an economy having the following characteristics: a country with a high potential of development and economic growth and high level of population and mainly young educated population. The economy is open to the rest of the world. In the economy not all the individuals hold bank accounts (Garg \& Agarwal, 2014). Those working in the formal economy and in public administration have bank accounts. The economy is a dual economy characterized by a formal and an informal economy. Both economies are interrelated (Timberg \& Aiyar, 1980). In the informal economy, there are MSMEs working as subcontractors for large firms in the formal economy. In the informal economy most of the businesses are family businesses. They remain informal mainly for fiscal reasons. They do not want to pay taxes to the state.

The state has one constraint which is the satisfaction of its people's needs. The well-being of the people is the main concern of the government. The people are happy when they can get access to the market for goods and services. They mainly use cash to exchange goods and services. This economy is a cash economy.

In the market of goods and services the demand is a negative function of price $D=f\left(P^{-}\right)$and the supply is a positive function of price $S=f\left(P^{+}\right)$. Moreover, the firms in both economies (formal and 
informal) produce goods with a fixed stock of capital, $K=\bar{K}$. In short term, the production function depends only on labour, $Q=f(L)$. Therefore, the marginal productivity of labour is diminishing, $f_{L}^{\prime}>0$ and $f_{L}^{\prime \prime}<0$.

At equilibrium in the market for goods and services $P^{*}=D^{*}=S^{*}=Q_{A}$. Let's consider that the need of all the people is not satisfied at equilibrium E. Therefore, this situation is characterized by poverty in the economy and unemployment. This equilibrium is underemployment equilibrium. The economy is presented in the figure below.

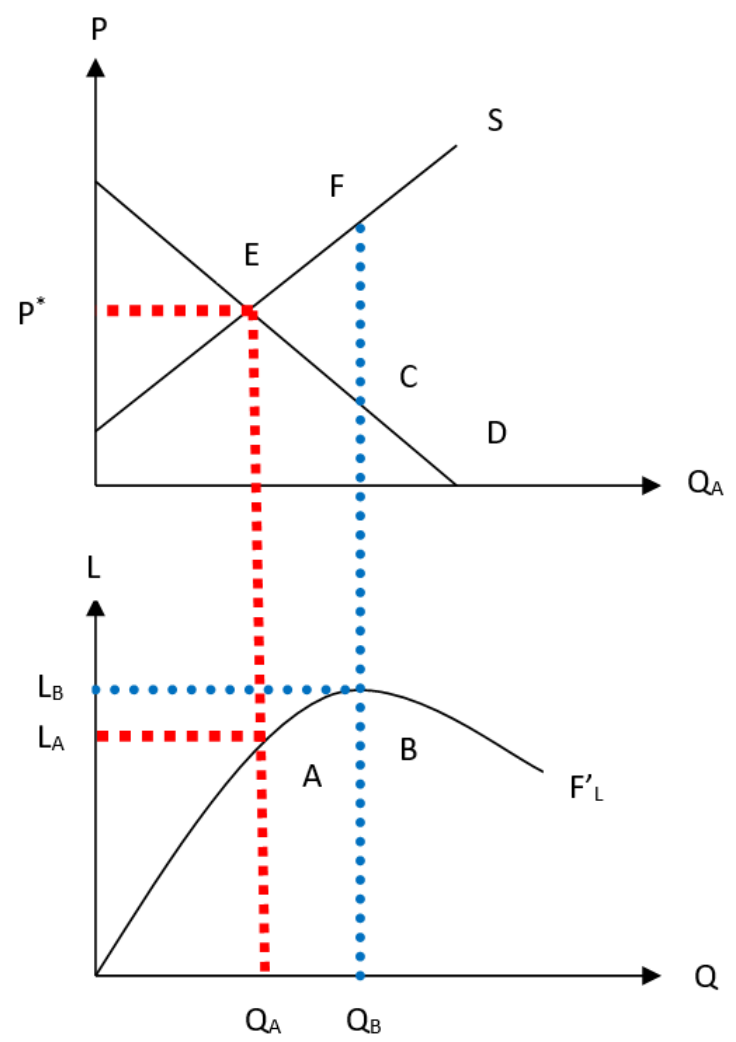

Figure 1. General Equilibrium

Source: Market for Goods and Services

In the market for goods and services there is equilibrium at point $\mathrm{E}$. We assume that the equilibrium is an in-optimal equilibrium in the sense that it reflects a suboptimal level of production corresponding to point $\mathrm{A}$. The quantity of good produced is $\mathrm{Q}_{\mathrm{A}}$ at equilibrium $\mathrm{E}$ which is given by the marginal productivity of labor $\mathrm{L}_{\mathrm{A}}$. As the quantity of goods produced is low, not all the consumers are satisfied. If the willingness to consume is high, consumers want to consume more goods to improve their well-being.

The maximum production of the economy is at point $\mathrm{B}$. The economy could produce $\mathrm{Q}_{\mathrm{B}}$ and the demand would be at point $\mathrm{C}$. Therefore, there is a potential for production growth in the economy. At $\mathrm{B}$, the economy would employ $L_{B}$ instead of $L_{A}$. The difference between $L_{A}$ and $L_{B}$ represents the level of unemployment: $U=L_{B}-L_{A}$.

The economy has two challenges. The first challenge is to increase the production level which has to rise from $\mathrm{Q}_{\mathrm{A}}$ to $\mathrm{Q}_{\mathrm{B}}$. The second challenge which is dependent on the first one is to increase employment.

The firms, knowing that there is a growing demand in the market for goods and services, satisfying the demand would increase their profit. Therefore, the potential profit of the firms is high. 
If we assume that the firms cannot increase the production because in the short run the stock of capital is fixed. Then to increase the production level, the firms will have to invest in productive capital. Indeed, companies cannot increase labour when the stock of capital is fixed. If they increase labour, the marginal productivity will decrease and the cost of production will increase. For example, if there is one employee that is using a computer, and then the firm hires another employee but has not invested in another computer. There will be two employees that are using one computer. Therefore, the marginal productivity of labor will decrease as long as the firm keeps on adding more employees. The ideal situation would be to invest in more computers, one computer for each employee. In this case, the marginal productivity of labour would be high and consequently the production of the company would be high. Hence, in order to increase the production the company has to invest in capital.

\section{MISMATCH IN THE CREDIT MARKET}

The firms demand for credit in the banking sector is necessary to sustain its economic growth. Banks can finance the economy through mainly three channels, money multiplier channel (Wang et al., 2017; Werner, 2016), the deposit channel (Li et al., 2017) and the credit channel (Werner, 2014). In a modern economy with developed banking systems, banks finance the economy through the credit channel. Giving credit to economic agents is a source of money creation (McLeay et al., 2014; Werner, 2014). Banks can supply loans to their customers regardless of their deposit.

In the case of the Indian economy, let's assume that the banking system is not modernized yet and only a few banks operating at the national and international level have modern infrastructure. For instance, Klomp and de Haan (2015) state that bank structure affects the reform of the banking sector. Stricter banking regulation reduces banking risk. Hence, the purpose of the demonetization reform is to given the opportunity to the banking system to get modernized and to reach the international standard. Therefore, the Indian banking system still functions with the old system implying that deposits make credit. The amount of loan given is decided in relation to the bank account balance. Let's assume that banks face liquidity constraint. In the credit market, demand for credit is higher than the supply of credit. In this case the interest rate will increase. The banks cannot supply credit to satisfy all the demands. Therefore, banks will rationalize credit and select companies (Brunnermeier, 2009). Moreover, in the economy, banks are facing bad loans (Chavan \& Gambacorta, 2016). Due to the interest rate being high, only MSMEs with good reputation and large firms can take the risk to borrow from the credit market at a high interest rate (Stiglitz \& Weiss). Credit rationing is detrimental to micro, small and medium companies who need more funds to sustain the economic growth (Parmar, 2015; Wehinger, 2013). In an industry organized in a chain of production, small and medium companies need to invest in order to meet the demand and to satisfy suppliers (large companies). Moreover, in the economy, economic growth is sustained only by private companies (Shimizu, 2010). Their increasing need for a loan is not satisfied (Swain, 2002). The demand is not satisfied also because of none performing loans (Chavan \& Gambacorta, 2016; Mohan, 2006).

How to solve the problem of credit rationing? If the problem remains, the economic growth will increase slowly and even in long run it will decline. Therefore, there is a matter for state intervention in the economy to adjust the disequilibrium in the credit market.

Through which mechanism can the state could intervene in the economy? The state has to understand the constraints of the economy. One of the constraints is loan limitation. The state should give opportunities to MSMEs to invest in the economy in order to increase the stock of productive capital and to keep on maintaining the economic growth high. The solution of the mismatch between demand and supply of credit in the credit market provided by the government is the demonetization policy. 


\section{THE DEMONETIZATION POLICY}

\subsection{Credit practices in the economy}

From the state point of view, in order to stimulate the economic growth the bank sector has to be reformed. One of the observations is that credit crunch occurs because banks lack liquidity. The other observation is households hold liquidity instead of savings in banks. Perhaps, poverty, economic and social uncertainty can explain the behavior of home saving. Therefore, there is liquidity in the economy circulating outside the banking system. This phenomenon is an obstacle for the economic development of the economy. If households save money in the bank, this institution will increase its liquidity and can provide firms with credit. In this economy, households have a high preference for liquidity. Hence, very few households have a bank account in this economy and it is mainly the case of those living in rural areas and urban poor (Garg and Agarwal, 2014). People working in the informal sector and semi-formal sector (a sector which is in between formal and informal sector, some of the firm's activities are formal and others are informal) do not have bank account (RBI, 2017). This is mostly the case in developing countries. These people mostly save money at home and hold other forms of financial assets like gold jewelries (Badarinza, 2016).

Due to not having a bank account and the preference of liquidity the state uses shock reform to motivate people to save their money in banks and to force them to open a bank account. This reform is called demonetization and consist of changing currencies. What is the purpose of this reform?

In the figure below, the households and the banks hold liquidity. The households and the banks fund the economy. As most of the MSMEs are family businesses, they use the family finance to invest in the business (Simon and Hitt, 2003). The MSMEs cannot rely on family finance to invest in the economy when the need for fund is higher than the financing capacity of the household. In the economy more funds are needed to sustain economic growth, to reach the level Qв (figure 1). They finance their investment also in the informal financial sector with moneylenders (Pradhan, 2013; Hoff and Stiglitz, 1997). Only banks can provide themthe high quantity of fund needed to invest in the business. The banks also face liquidity constraints. Banks need savings. If people save money at home instead of saving it in banks, the companies cannot get fund to invest in the economy.

The banks deposit money with the central bank therefore, they can fund the economy in relation with the quantity of money deposited within the central bank. The bank sector has to grow in order to fund the economy. The figure below represents the funding circuit in our economy. Microfinance is excluded in the circuit.

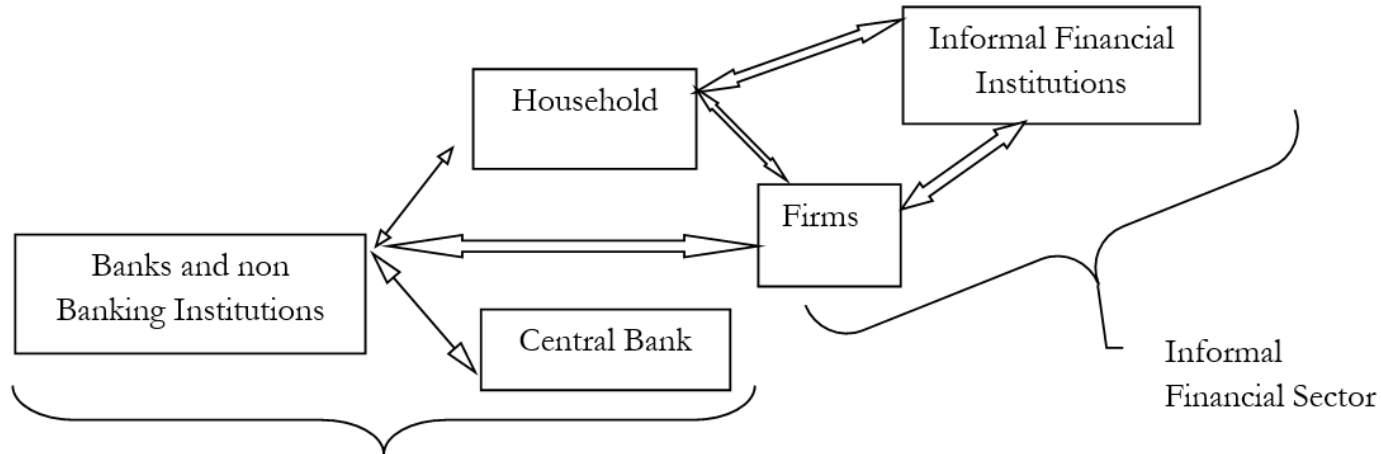

Formal Financial Sector

Figure 2. Financing circuits 


\subsection{The purposes of the policy}

As most of the MSMEs finance their investment within the internal circuit, which is an informal circuit of finance, it is assumed that the state wants to reduce the extent ofthis form of transaction. In other words, the state wants to formalize the credit transaction for better transparency, accountability and responsibility. Therefore, the state can have better control on the credit transaction and can impose taxes on companies and banks.

The argument is that when the banks get liquidity from savings, they can lend money to firms to finance the economy. The firms will increase the stock of productive capital and increase labor force. Therefore, economic growth will increase.

This policy will allow the government to impose tax on credit transactions (Dash, 2017) and will allow people to earn an income which will support the economic growth and development of the economy. The informal circuit of lending money is an opportunity cost for the state. This opportunity cost has to be reduced or eliminated.

\section{DEMONETIZING THE ECONOMY: FIGHTING AGAINST INFLATION}

The fight against inflation has become one of the main objectives of all the central banks throughout the world and mainly in developed countries (European Union and the USA). The fight against inflation gives a positive sign to the market. Therefore, it also shows that the government will use the monetary policy less to increase growth. It is also a positive sign addressed toward the market that the central bank will be neutral and independent. This policy can only be effective if the banking and the overall financial system is formalized. The liberalization of the financial system requires formal financial institutions capable to fund the economy.

The risk of an important informal financial market where tremendous amount of money circulates is inflation. Therefore, the process of creation and destruction of money lengthens which can generate inflation if new money is created through the formal circuit of lending and money creation from the central bank, without going through the formal destruction channel. There is destruction of currency when the bank notes enter the banks account or the central bank.

The risk of inflation is rather high when the channel for money creation is supplied by fake or black money. Let's assume that there is a possibility for black money to circulate in the economy. The black money increases the stock of money in the economy. The black money is therefore invested in the economy.

Let's consider Fisher's equation also known as the quantity money theory.

$$
M v=P Y
$$

$M$ describes the stock of money, $v$ the velocity of money. $M v$ represents the supply of money. According to this model, there is a dichotomy between the monetary sphere $(M v)$ and the real sphere $(P Y)$. The real sphere is represented by $P$ which is the price for goods and services and $Y$ the output of the economy. As there is dichotomy between these two spheres the stock of money does not influence the output $Y$ whereas, the output influences the stock of money. The right hand side of the equation represents the demand for money and the left hand side of the equation is the supply of money. One of the main functions of the currency is to ease transaction in the economy. The stock of money $M$ is created in the formal sector (central bank and lending process) in respect with the demand for money PY. In the model $v$ the velocity of money is considered fix in short term. If the stock of money is increased through an informal circuit via black money it affects the economy. As there is dichotomy between the two spheres, black money increasing the stock of money in circulation in the economy and has an impact of the price for goods and services. Black money creates inflation. 
Moreover, the risk of inflation is also high not because of black money but due to the money saved at home. Regardless of the householders' living standard, all the citizens in the economy save money at home but it is particularly the case for the middle and upper class households and those owning businesses. Most of these people prefer keeping money at home instead of depositing it at the bank because they would have to declare their source of income and pay taxes.

In this case, we assume that the velocity of money is no longer constant. Imagine that people start using their money saved at home. There would be more and more money used in the economy. The stock of money will increase. Here we have two scenarios; first, the central bank creates money because $Y$ increases. If there is a delay in money creation, the households will start using their own money to satisfy their need. Therefore, more money will be in circulation in the economy the old currency and the new currency created by the central bank. The risk of inflation is therefore high. In a dynamic environment, the equilibrium in the money market is given as follows

$$
\begin{aligned}
\ln (M v) & =\ln (P Y) \\
\ln M+\ln v & =\ln P+\ln Y
\end{aligned}
$$

The derivatives of $\ln$ in relation with time imply:

$$
\frac{\Delta M}{M}+\frac{\Delta v}{v}=\frac{\Delta P}{P}+\frac{\Delta Y}{Y}
$$

If the velocity of money is uncertain in the economy because of home saving and there is irregular use of this money we cannot assume that $\frac{\Delta v}{v}$ is constant. The inflation rate is $\frac{\Delta P}{P}$, we note $\pi$ as the inflation rate. Thus we can deduce an equation of the inflation rate:

$$
\pi=\frac{\Delta M}{M}+\frac{\Delta v}{v}-\frac{\Delta Y}{Y}
$$

The inflation rate depends on the growth rate of stock of money, the growth rate of velocity and the growth rate of aggregate output.

The second scenario is that the central bank does not create money, because there are a lot of currencies in the economy. In this scenario, people will use their own money which will supply money in to the economy. People will use their home saving to satisfy their demand. Hence, inflation in this scenario increases. The rate of inflation will depend on the quantity of home money used by the households.

By demonetizing the economy, the government seeks to reduce home saving to force the household to save money in banks. The aim of this policy is to reduce $\frac{\Delta M}{M}$ the growth rate of money stock. One of the mechanisms to force households to save money in banks is to replace the old currency by new currency. Therefore, the old currency will become useless. The only way to avoid loss in value, in other words to avoid people losing their financial assets is to motivate them to deposit money in banks. Hence, those who do not hold bank accounts have to create one. Holding a bank account will allow individuals to deposit money and withdraw money easily from bank with a debit card.

The objective of the government is to digitalize the economy. Indeed, with this policy the government wants to increase the velocity of money. Indeed, when the velocity of money is high, the process of creation and destruction of money is also high. For instance, if an individual buys a good and pays with his debit card, the transaction involves simultaneous creation and destruction of money. Therefore, when the velocity of money is high, the impact of money circulation in the economy is low $\frac{\Delta v}{v} \rightarrow 0$. In this case, the velocity rate will become stable and constant, meaning that the impact of inflation is low. Therefore, the aim of the government is to increase the velocity of money in the 
economy. Indeed, if $\frac{\Delta M}{M}$ remains unchanged as well as $\frac{\Delta Y}{Y}$, therefore, when $\frac{\Delta v}{v}$ decreases, it implies a decrease in $\pi$.

In the case of digitalization of the economy, the central bank can become completely independent without having to intervene in the economy to adjust the equilibrium in the money market. The equilibrium must be adjusted automatically in relation with supply and demand for money in the money market. If $\frac{\Delta M}{M}$ and $\frac{\Delta v}{v}$ remain constant, therefore, the inflation rate depends only on economic growth rate $\frac{\Delta Y}{Y}$. Therefore, as long as there is equilibrium in the market for goods and services, the inflation rate will remain low.

This economy amongst the other economies in the world and among the emerging countries has a poor banking system which is not competitive enough to face competition in a globalized world (Shimizu, 2010). The reform aims to modernize the banking system, giving them the financial asset to compete with international banks. This is specially the case of a growing economy. If banks are not competitive enough firms would be funded by international banks. By depositing money in banks, this institution will receive a high quantity of liquidity allowing them to compete with international banks in financing the economy.

\section{MAKE-IN POLICY}

The make-in policy consists of encouraging foreign investors to invest in the economy. Indeed, the economy faces capital shortage to continue on keeping the economic growth high. The local firms because of capital and technology limitation cannot increase in high quantity stock of capital in economy. Therefore, there is a necessity to encourage foreign investors to invest in the economy.

It is supposed that foreign investments will boost the economic activity which brings technology in the country to push one step forward in the economic development. There are two kinds of foreign investment: low capitalistic investment (labour intensive investment) and high capitalistic investment. The aim of the government is to attract high capitalistic investment. Indeed, the economy is no longer a low skill economy or a high labour intensive economy. The economy is an emerging economy characterized by a high level of educated labour force and highly competitive companies. Highly capitalistic companies will invest in the economy and transfer technology and skill (Kabelwa, 2004) only if there is a high level of educated labour force capable to efficiently use the technology. Therefore, this kind of FDI will increase productivity and thus boost the economy growth to a higher level (Buckley et al. 2006; Blomström \& Kokko, 2003). Therefore, at the macroeconomic level, there will be an improvement in living standards, reduction of poverty and economic and socio-cultural development (Rutihinda, 2007; Dupasquier \& Osakwe, 2005).

The make-in policy aims to attract Foreign Direct Investment (FDI) in order to reduce unemployment and to increase the stock of capital in the economy. There are three kinds of FDI: market seeking, asset seeking and efficiency seeking (Fontagné \& Lorrenzi, 2005) and their impacts on the economy are different(Bhatt, 2013). The portfolio investment may not have a positive impact on the economy when foreign investors are only attracted by the return on investment. This form of FDI has a limited impact on economic growth. Foreign investors invest in local companies knowing that there is a high profit potential in the economy as the economic growth is high. The impact of FDI inflows can be low on economic growth and job creation (Chakraborty \& Basu, 2002). Most of the time this is a short term investment. Bhat et al. (2004) suggest that labour intensive companies have benefited less from positive externalities of FDI.

We assume that the government is more attracted by productive FDI (market seeking and efficiency seeking FDIs as companies invest in the economy by producing good and services which requires a 
workforce, in turn creating jobs. The decision to outsource production depends on several criteria such as, financial and strategic and managerial strategies. Companies take the market opportunities, quality of institutions and also quality of infrastructures into consideration before making their decision to investing in foreign economies.

Foreign investors can work in partnership with local companies, it mainly happens in the R\&D sector. Foreign companies can open unit of production in the country. They can purchase local companies or merge with them. Foreign companies can outsource the production to local producers as it is the case of the multinational firm Nike. In most of the cases foreign companies do not invest in advanced technologies because intellectual property protection is weak (Athreye \& Kapur, 2001).

To attract highly capitalistic companies, those firms being able to absorb the highly educated population, the government needs to offer some attractive conditions. One of the conditions is a sound economic environment which is an environment without corruption. Indeed, corruption involves extra cost of production which is hardly bearable by foreign companies. Moreover, the financial sector must be modernized and liberalized. The liberalization of the financial market implies less control on capital movement. Therefore, these companies can freely move their profit to their country of origins. If there is modern banking and financial system these companies can get fund easily to invest in the local market. The demonetization is a complementary policy to make in policy. Indeed, the demonetization policy will change the behavior of consumers. The transaction will be safer. The price in the goods and services market will be fixed. The consumers would not have to bargain. This is a condition to enhance trade in the market. Foreign companies are not used to bargaining. Moreover, more people will get access to the market. The size of the market will increase. Therefore, the potential of development and economic growth would be high.

Imagine, in spite of all this effort FDI inflow is low and also not to be dependent on foreign companies for its own development. However, the economy still needs liquidity to invest in the economy to catch its economic and development gap with other emerging countries. Therefore, demonetization is a policy to fill up this gap. It forces the households to deposit money in the banks which will be used to finance the economy. The aim of government is to project the economy in the $21^{\text {st }}$ century and to challenge the current and futures issues with its own resources and forces.

\section{CONCLUSION}

Demonetization is a highly debatable issue whether it is successful or a failure. The focus of this paper is not to discuss these issues but just to explain why the government was motivated to implement such a policy. From a hypothetical case we tried to conceptualize the issue of demonetization. The main conclusion would be that the government has implemented this policy in order to modernize the banking sector which is necessary if the economy would like to compete with more developed and advanced economies technologically and financially. The banking system in the economy lacks liquidity to sustain the economic growth and the development of companies. Whereas, there are a lot of money circulating outside the formal circuit. There is a risk of inflation when the process of creation and destruction of currency is disrupted. To limit the risk of inflation the government need to modernize the economy and thus to digitalize the economy which means the economy have to become a cashless economy.

The policy of demonetization is embedded to the make-in policy. When the economic institutions are efficient and less corrupt as well as modernized, the economy can attract high value FDI. Therefore, this kind of investment will create high value jobs in the economy.

It is necessary to acknowledge that this policy has risk. There are risks related to demonetization which will be analyzed in another article. 


\section{REFERENCES}

Aitken, B., \& Harrison, A.E. (1999). Do domestic firms benefit from foreign direct investment?. The American Economic Review, 89(3), 605-618.

Allen, F., Chakrabarti, R., De, Sankar, Qian, J., \& Qian, M. (2012). Financing firms in India. Journal of Financial Intermediation, 21(3), 409-445.

Athreye, S., \& Kapur, S. (2001). Private Foreign Investment in India: Pain or Panacea?. The World Economy, 24, 399424.

Badarinza, C., Balasubramaniam, V., \& Ramadorai, T. (2016). The Indian Household Savings Landscape. India Policy Forum/NCAER, July 12-13 2016.

Bhatnagar, H. (2017). Demonetization to Digitalization: A Step Toward Progress. Management and Economics Research Journal, 3, 11-15.

Bhat, K.S., Sundari, T.C.U., \& Raj, K.D. (2004). Causal Nexus Between Foreign Direct Investment and Economic Growth in India. Indian Journal of Economics, 85(337), 171-185.

Bhatt, P.R. (2013). China's Exports and Foreign Direct Investment. Applied Economics and International Development, 13(2), 187-200.

Blomström, M., \& Kokko, A. (2003). The Economics of Foreign Direct Investment Incentives. EIJS Working Papers, 168, Stockholm, Sweden.

Brunnermeier, M. K. (2009) Deciphering the Liquidity and Credit Crunch 2007-2008. Journal of Economic Perspective, 23(1), 77-100.

Buckley, J.P., Clegg, J., \& Wan, C. (2006). Inward FDI and Host Country Productivity: Evidence from China's Electronic Industry. Transnational Corporation, 15(1), 13-37.

Chakraborty, C., \& Basu, P. (2002). Foreign Direct Investment and Growth in India: A Cointegration Approach. Applied Economics, 34(9), 1061-1073.

Chakraborty, C., \& Nunnenkamp, P. (2008). Economics Reforms, FDI, and Economic Growth in India: A Sector Level Analysis. World Development, 36(7), 1192-1212.

Chavan, P., \& Gambacorta, L. (2016). Bank Lending and Loan Quality: The Case of India.BIS Working Paper, No. 595.

Dash, A. (2017). A Study on Socio Economic Effect of Demonetization in India. International Journal of Management and Applied Science, 3(3), 13-15.

Dollar, D., \& Kraay, A. (2002). Growth is Good for the Poor. Journal of Economic Growth, 7(3), 1995-225.

Dupasquier, C., \& Osakwe, P.N. (2005). Foreign Direct Investment in Africa: Performance, Challenges and Responsibilities. Journal of Asian Economics, 17(2), 241-260.

Fontagné, L., \& Lorenzi, J.H. (2005). Désindustrialisation, Délocalisation. La Documentation Française, Paris, 2005.

Ganesan, G., \& Gajendrayanagam, B. (2017). Impact of Demonetization on Indian Economy. International Journal of Applied Research, 3(9), 433-436.

Guérin, I., Lanos, Y., Michiels, S.,Nordman, C.J., \& Venkatasubramanian, G. (2017). Insights on Demonetisation from Rural India: Understanding Social Networks and Social Protection. Economic and Political Weekly, 52(52), 44-53.

Hoff, K., \& Stiglitz, J.E. (1997). Moneylenders and Bankers: Price-Increasing Subsidies in a Monopolistically Competitive Market. Journal of Development Economics, 52(2), 429-462.

Kabelwa, G. (2004). South African FDI in East Africa: The Case of Tanzania. Dar es Salaam. ESRF, Globalization and East Africa, Working Paper Series No. 10.

Klomp, J., \& de Haan, J. (2015). Bank Regulation and Financial Fragility in Developing Countries: Does Bank Structure Matter?. Review of Development Finance, 5(2015), 82-90.

Kumar, R., \& Vashisht, P. (2011). Crisis, Imbalances, and India. ADBI Working Paper 272. Tokyo: Asian Development Bank Institute. http://www.adbi.org/workingpaper/2011/03/29/4497.crisis.imbalances.india/

Li, B., Xiong, W., Chen, L., \& Wang, Y. (2017). The Impact of the Liquidity Coverage Ratio on Money Creation: A Stock-Flow Based Dynamic Approach. Economic Modelling, 67(2017), 193-202.

Mali, V. (2017). Demonetization: A Step towards Modified India. International Journal of Commerce and Management Research, 2(12), 35-36. 
McLeay, M., Radia, A., \& Thomas, R. (2014). Money Creation in the Modern Economy. Quarterly Bulletin, 2014, Q1, 1-14.

Mohan, R. (2006). Agricultural Credit in India: Status, Issues and Future Agenda. Economic and Political Weekly, 41(11), $18-24$.

Parmar, B. (2015). Small, Medium Sector Face Credit Crunch. The Hindu, Business Line, 8 December 2015, www.thehindubusinessline.com/money-and-banking/small-medium-sectors-face-creditcrunch/article7962319.ece

Pradhan, N. (2013). Persistence of Informal Credit in Rural India: Evidence from 'All-India Debt and Investment Survey' and Beyond. MPRA Paper, No. 80381, https://mpra.ub.uni-muenchen.de/80381/

Pwc. (2017). Family Business Survey2012-2013. Pwc.in.

Ramdurg, A.I., \& Basavaraj, C.S. (2016). Demonetization: Redefining Indian Economy. International Journal of Commerce and Management Research, 2(12), 7-12

Reserve Bank of India (RBI). (2017). Macroeconomic Impact of Demonetization-A Preliminary Assessment. Reserve Bank of India, 10 March 2017, India

Rutihinda, C. (2007). Impact of globalization on small and medium size firms in Tanzania. Hawaii: ABR and TLC Conference Proceedings.

Shimizu, S. (2010). The State of the Indian Banking System and Its Role in India's High Growth. Pacific Business and Industries, 10, No 36, 2010

Shirley, A.J. (2017). Impact of Demonetization in India. International Journal of Trend in Research and Development, Special issue, 20-23, www.ijtrd.com.

Simon, D.G., \& Hitt, M.A. (2003). Managing Resources: Linking Unique Resources, Management, and Wealth Creation in family Firms. Entrepreneurship Theory and Practice, 27(4), 339-358.

Singhal, R., Sawai, Kumar, Subham, J., \& Rajat, N. (2017). Demonetization in India. International Journal of Engineering and Management Research, 7(2), 137-138.

Stiglitz, J.E., Weiss, A. (1981). Credit Rationing in Markets with Imperfect Information. The American Economic Review, 71(3), 393-410.

Swain, R.B. (2002). Credit Rationing in Rural India. Journal of Economic Development, 27(2), 1-20.

Timberg, T., \& Aiyar, C.V. (1980). Informal Credit Markets in India. Economic and Political Weekly, February Annual Number, 1980.

Wang, W., Fu, H., \& Wang, Y. (2017). Money Creation and Circulation in a Credit Economy. Physica A, 465(2017), 425-437.

Wehinger, G. (2013). SMEs and the Credit Crunch: Current Financing Difficulties, Policy Measures and a Review of Literature. OECD Journal: Financial Market Trends, 2013/2.

Werner, R. A. (2016). A Lost Century in Economics: Three Theories of Banking and the Conclusive Evidence. International Review of Financial Analysis, 46(2016), 361-379.

Werner, R.A. (2014). How Do Banks Create Money, and Why Can Other Firms Not Do the Same? An Explanation of Coexistence of Lending and Deposit taking. International Review of Financial Analysis, 36(2014), 71-77.

World Bank. (2017). Innovative Early Stage Financing for SMEs in India. August 10, 2017, http://www.worldbank.org/en/news/feature/2017/08/10/innovative-early-stage-financing-for-smes-inindia 